\title{
Lernaeocera branchialis (L., 1767) on cod in Baltic waters
}

\author{
G. Sundnes ${ }^{1}$, J. Mork, P. Solemdal ${ }^{2}$ \& K. Solemdal ${ }^{2}$ \\ ${ }^{1}$ The Royal Norwegian Society of Sciences and Letters Foundation; 7013 Trondheim, \\ Norway \\ ${ }^{2}$ Institute of Marine Research, Bergen, Norway
}

\begin{abstract}
Field surveys have shown a limited distribution of $L$. branchialis in Baltic waters due to heterogenic salinity. The parasite is not suited as "natural" tagging of the cod population in these waters.
\end{abstract}

\section{INTRODUCTION}

The parasitic copepod Lernaeocera branchialis (L.) on cod in Nordic waters was described for the first time by Strøm (1762).

There are two parasitic stages in the life cycle of $L$. branchialis. The first stage is found on species in several families (Sundnes, 1970). In the first period of development, the parasite goes through several developmental stages until copulation takes place. After copulation the female swims freely until it attaches to the final host. Only the female has this second stage of development. The male dies after copulation.

This second stage is mainly found on gadoid fish, but also other fish families can be final hosts for L. branchialis (Kabata, 1958).

The mature female has easily detectable "egg strings" (Fig. 1) which are segmented, embryos being continuously released from these.

The parasite has a pathogenic effect on the cod that varies in degrees. The pathogenic effect is dependent on the size of the fish as well as on ecological conditions in the specific cod population (Sundnes, 1970; Kahn, 1994).

This paper presents some observations on L. branchialis parasitizing cod in Baltic waters. The possibility to use the parasite as a "natural" tag of cod populations in these waters is also briefly discussed. Sherman \& Wise (1961) considered that $L$. branchialis could be a "natural" tag of fish populations in the New England area, while the findings of Arntz (1972) concerning $L$. branchialis infecting fishes in the Kiel Bay do not justify its use as a "natural" tag in these waters. In Atlantic waters the host penetrates further south than the parasite on both sides of the ocean. The ecological background for the limited southern distribution of the parasite in Atlantic waters is not known. In Baltic waters, in conditions of heterogenic salinity, the limited distribution of the parasite could be due to lack of osmoregulation in the parasite (Sundnes, 1970). These experimental findings of Sundnes (loc. cit.) indicated that the parasite would not thrive in salinity below $18 \%$. 


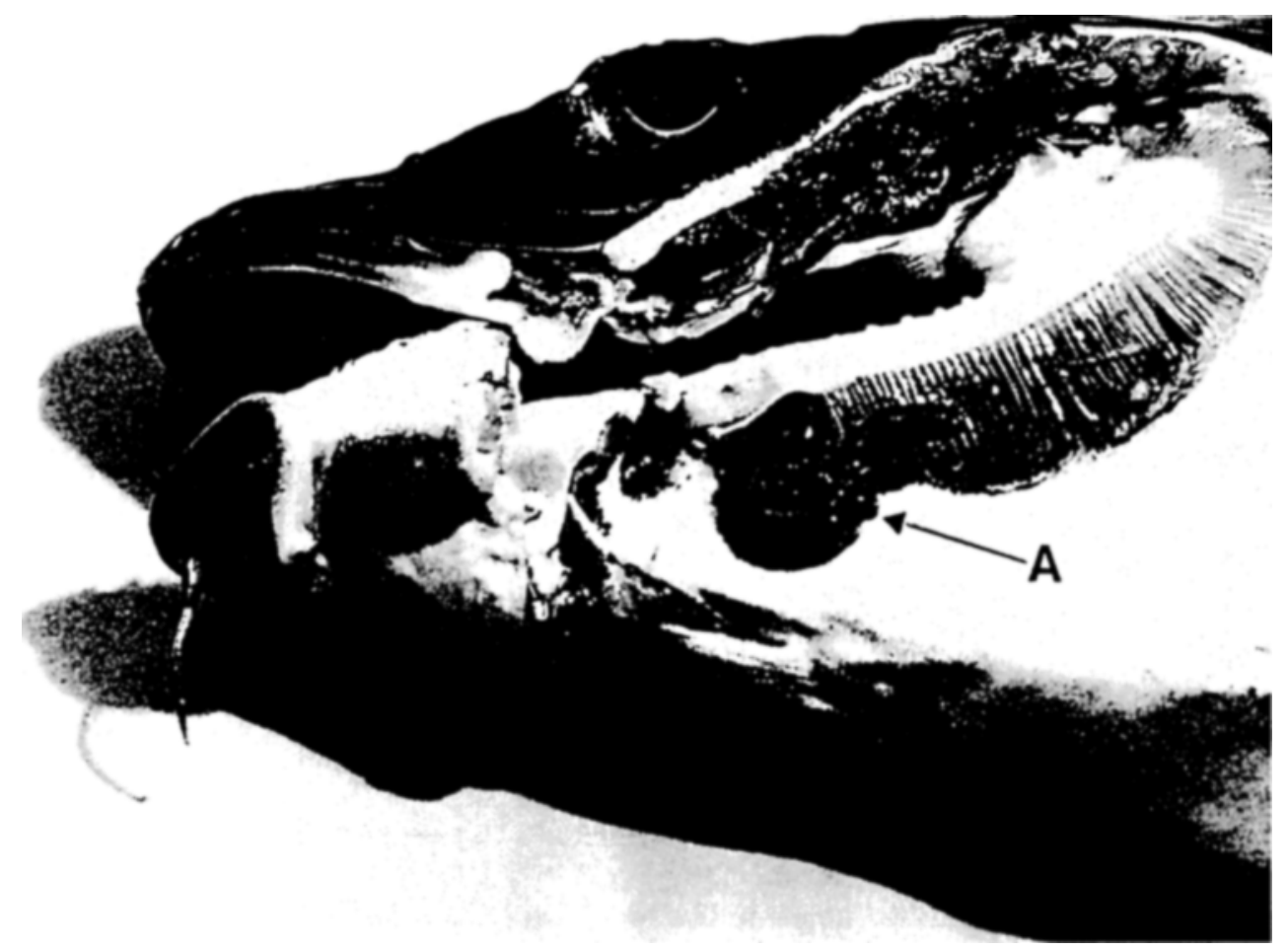

Fig. 1. Cod infected with Lernaeocera branchialis (A) with developed "egg" strings

\section{RESULTS AND CONCLUSION}

During a survey in Baltic waters in 1972 with R. V. "Alkor" from the Institut für Meereskunde in Kiel, 2356 cod were examined from 7 trawl stations (cf. Fig. 2 and Table 1). At the westernmost station in the fished area, only one Lernaeocera branchialis was found among $1081 \mathrm{cod}$. At this locality the salinity of the water was $24.5 \%$. At the other trawl stations no parasites were found. No salinity data east of $15 \mathrm{E}$ were taken on this survey. Arntz (1972) found the same situation in Kiel bay where an infection rate in cod of $0.1 \%$ was found.

He concluded his findings were possible because of an inflow of salt water from the Kattegat. Our finding of an infection rate of $0.1 \%$ at station 7 must be considered to be a coincidence.

In 1985, a field survey was performed in the coastal waters off the Norrby laboratory (University of Umeå, Sweden). Twenty-three cod were caught by gillnets for parasite analyses and osmolality measurements. The salinity was $4.8 \%$ and $5.9 \%$ at 0 and 22 meters depth, respectively. Even in these salinities the cod had normal osmolality (Table 2). Two specimen of cod (fish no: 6 and 11), both females, had significant lower osmolality. One 


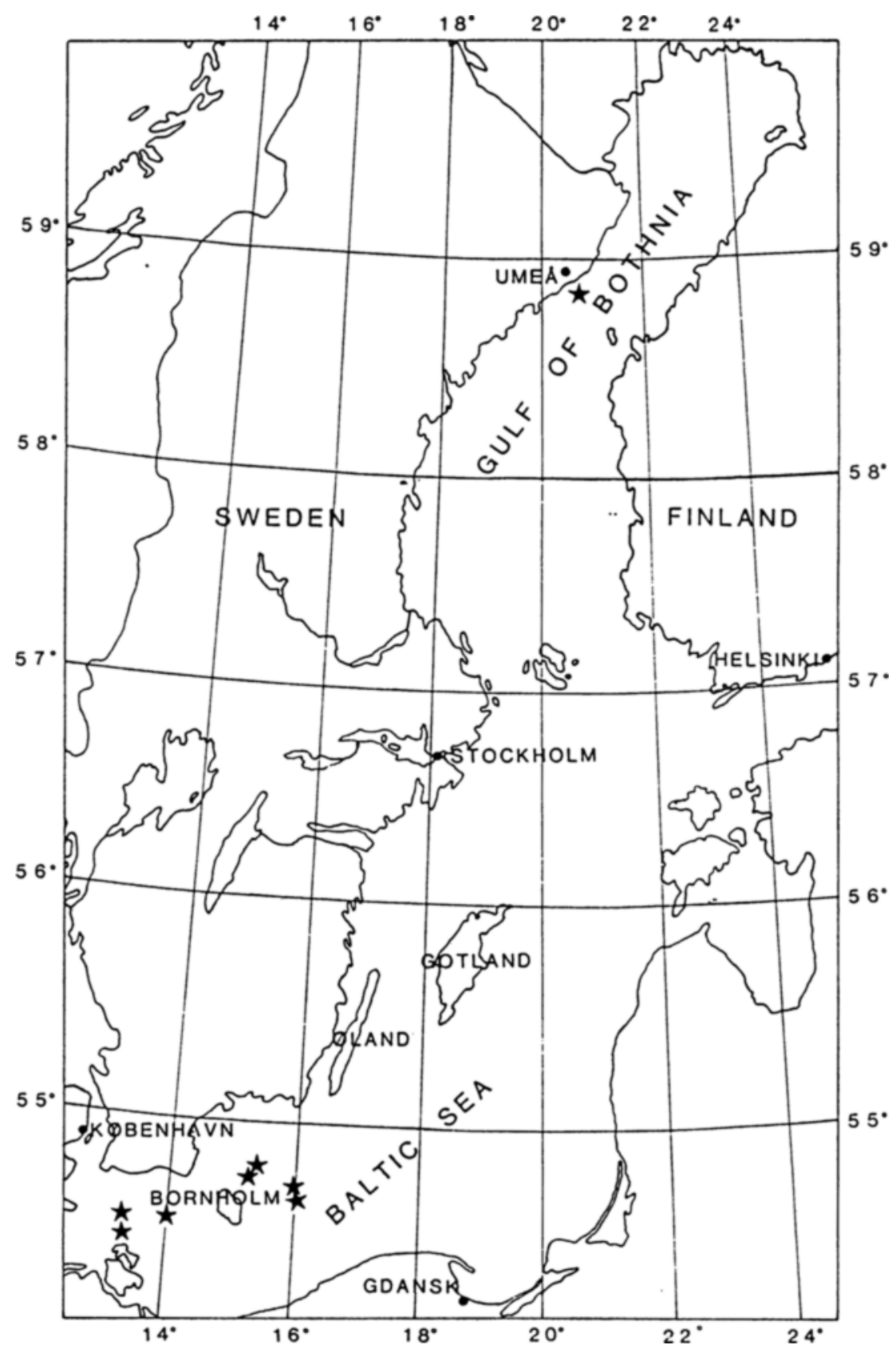

Fig. 2. Map of Baltic waters with fishing locations $(\star)$ in the Bornholm area and in the vicinity of Umeå 


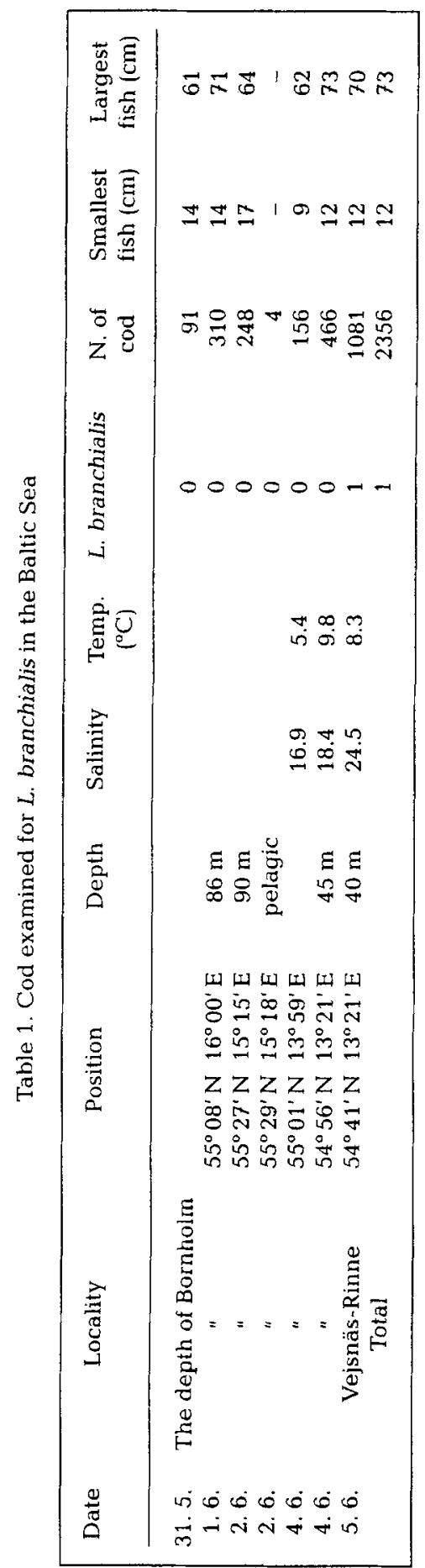


Table 2. Osmolality in cod off the Norrby Laboratory

\begin{tabular}{|c|c|c|c|c|}
\hline Fish no. & Sex & $\begin{array}{l}\text { Body length } \\
\text { (cm) }\end{array}$ & m. Osm & L. branchialis \\
\hline 1 & Female & 62 & 382 & 0 \\
\hline 2 & $"$ & 59 & 382 & 0 \\
\hline 3 & $"$ & 67 & 338 & 0 \\
\hline 4 & $"$ & 76 & 316 & 0 \\
\hline 5 & $n$ & 68 & 357 & 0 \\
\hline 6 & $"$ & 73 & 289 & 0 \\
\hline 7 & $"$ & 73 & 329 & 0 \\
\hline 8 & $"$ & 56 & 346 & 0 \\
\hline 9 & $"$ & 59 & 333 & 0 \\
\hline 10 & $"$ & 62 & 365 & 0 \\
\hline 11 & " & 61 & 288 & 0 \\
\hline 12 & $"$ & 61 & 356 & 0 \\
\hline 13 & $"$ & 56 & 368 & 0 \\
\hline 14 & Male & 59 & 310 & 0 \\
\hline 15 & $"$ & 55 & 355 & 0 \\
\hline 16 & $"$ & 56 & 354 & 0 \\
\hline 17 & $"$ & 79 & 307 & 0 \\
\hline 18 & $"$ & 66 & 368 & 0 \\
\hline 19 & $"$ & 64 & 312 & 0 \\
\hline 20 & $"$ & 57 & 360 & 0 \\
\hline 21 & $"$ & 72 & 316 & 0 \\
\hline 22 & $"$ & 53 & 331 & 0 \\
\hline 23 & $"$ & 41 & 346 & 0 \\
\hline 24 & $n$ & 61 & 354 & 0 \\
\hline 25 & $"$ & 58 & 370 & 0 \\
\hline 26 & " & 76 & 340 & 0 \\
\hline 27 & $"$ & 61 & 356 & 0 \\
\hline 28 & $"$ & 56 & 368 & 0 \\
\hline
\end{tabular}

had abnormal gonads and the other a liver in a pathological condition. This may reduce their ability to hold stable osmolality.

Panikkar \& Sproston (1941) postulate that $L$. branchialis can keep up with a stable osmolality due to the connection to the host and its body liquids. The present findings however demonstrate that the parasite is dependent on the salinity of the surrounding water. Waters of salinity below $20 \%$ are important ecological factors for the osmolality of the parasite, thereby limiting the distribution of the parasite. The host, however, can penetrate through the salinity barriers into waters of salinity less than $5 \%$ and still maintain normal osmolality. The "tagging" value of this parasite on the cod population is low in these waters. 


\section{LITERATURE CITED}

Arntz, W. E., 1972. Über das Auftreten des parasitischen Copepoden Lernaeocera branchialis in der Kiel Bucht und seine Bedeutung als biologische Markierung. - Arch. FischWiss. 23, 118-127.

Kabata, Z., 1958. Lernaeocera obtusa n. sp. Its biology and its effect on the haddock. - Mar. Res. 3, $1-26$.

Khan, R. A., 1994, Parasites as potential pathogens in atlantic cod mariculture. - C.M./ICES, F 22, $1-5$.

Panikkar, N. K. \& Sproston, N. G., 1941. Osmotic relations of some metazoan parasites. - Parasitology $33,214-223$.

Sherman, K. \& Wise, J. P., 1961. Incidence of the cod parasite Lernaeocera branchialis in the New England area, and its possible use as an indicator of cod populations. - Limnol. Oceanogr. 6 , 61-67.

Strøm, H., 1762. Physisk og Oeconomisk Beskrivelse over Fogderiet Søndmør beliggende i. Bergens Stift i Norge. Strøm, Sorøe, 1, 1-552.

Sundnes, G., 1970. Lernaeocera branchialis (L.) on cod (Gadus morhua L.) in Norwegian waters. Institute of Marine Research, Bergen, 48 pp. 